THE KURUME MEDICAL JOURNAL

Vol. 37, Supplement, p. S127-S128, 1990

\title{
Treatment of Vibration Syndrome in Finland
}

\author{
MARKUS FÄRKKIL $\dddot{A}$ AND ILMARI PYYKKÖ \\ Departments of Neurology and Otorhinolaryngology, University Hospital of \\ Helsinki, Haartmaninkatu 4, 00290 Helsinki, Finland
}

Received for publication June 30, 1989

Vibration syndrome, or traumatic vasospastic disease, arose in Finland in the 1960s; when chain saws became lighter and more effective, and a whole day of exposure was possible.

Vibration exposed workers have been studied since 1972 in Finland, and there has been a change in the prevalence and severity of vibration induced symptoms among forest workers (Pyykkö et al. 1986).

As the vibration syndrome does not develop by only one mechanism (Färkkilä, 1978), the treatment and prevention is dependent on the factors causing the symptoms.

In Finland the patient with vibration syndrome is compensated only when the following criteria are fulfilled: 1) he has been exposed to vibration long enough to develop the syndrome, and 2) all other diseases have been excluded, such as primary Raynaud's disease, collagen diseases, injuries and thoracic outlet syndromes. The patient with vibration syndrome is compensated only, when there are findings in at least two different tissues or organs, like white fingers as a sign of vasospastic disease, and EMG changes as a sign of neuropathy.

The impairment from vibration induced white fingers or numbness is considered mild, and the estimated degree of invalidity is only $10-20$ per cent. The patient is expected to work in professions without vibration exposure.

In Finland autonomic symptoms and neck and shoulder symptoms are consid- ered to be due to strenuous muscle work, temporary reversible stress and not linked to vibration exposure. Most patients are treated by general practioners who recommend lighter work, physiotherapy or drugs without compensation. If the patient fullfills the above criteria, the insurance company will pay for the treatment of symptoms which are definitely due to vibration exposure.

All vibration exposed workers have had compulsory annual health examinations for hearing loss and hand arm symptoms paid for by the employer.

\section{Treatment}

Treatment involves four main lines. First, attempts are made to eliminate the exposure. Second, the symptoms are reduced by physiotherapy or ergonomic improvements. Third, symptomatic drugs are administered and fourth, operations are performed.

In Finland, most treatment regimens consist of technical hygienic improvements of working conditions, isolation of the vibration, diminishing cold and noise exposure, and moving the worker to other jobs without vibration exposure. Pyykkö et al. (1978) have shown that these changes in forestry workers reduced the prevalence and severity of vibration induced white fingers, numbness and diminution of muscle force in the hands. Also a change in grinding machines to 
the older type with less power, prevented white fingers, because workers could not compress the metal castings against the wheel as tightly as they could with modern, high-energy machines. (Starck et al. 1983). Workers who tightly compress the tool, are more prone to develop VWF, and thus the compression force should be reduced (Färkkilä et al. 1979).

Physiotherapies have largely been applied to the neck muscle tension symptoms and to the back pain, which are not considered to be due to vibration. The routine physiotherapy consists of electromechanic short wave warming of deep muscles, gymnastics and movements of arms and neck, and massaging of the shoulders or back. Most forest workers prefer only massage for their painful muscles. No baths or galvanic therapies are used in Finland as routine treatment for the vibration syndrome.

Drug therapies are seldom used for vascular symptoms. The most effective drug has been nifedipine, a calcium entry blocker, but the effect is short lasting. The effectiveness was shown by Harada et al. (1986) in a double-blind cross-over study with nifedipine, $5 \mathrm{mg} \times 2$. We might recommend a little higher dose, if the side effects are tolerated. (Adalat 5-10 $\mathrm{mg} \times 3$, or Depotcaps $20 \mathrm{mg} \times 1$ ). Other calcium entry blockers might also be useful, like diltiazem, but we have no experience with them. Prazosin (Peripress $1-2 \mathrm{mg} \times 3$ ) had acceptable effects during temporary use. Clonidine (Catapresan) did not alter the vascular symptoms (Pyykkö and Färkkilä, 1982). The pain and stiffness of muscles are the most prominent symptoms, and nonsteroidal anti-inflammatory drugs, like tolphenamic acid, (Clotam $200 \mathrm{mg} \times$ 2-3), diclophenac, (Voltaren $50 \mathrm{mg} \times 3$ ), or indomethacin (Confortid $50 \mathrm{mg} \times 2-3$ ) can be used.

Surgical therapies like sympathectomy for vasospastic symptoms have been tried with poor results, and should not be used for vibration induced white fingers. Operations for carpal tunnel entrapment also have limited value. Spontaneous recovery often occured, but not all the operated patients improved. Thus the operation for carpal tunnel is not recommended as a first line therapy for vibration induced carpal tunnel symptoms (Koskimies et al. 1989).

\section{References}

FӓвкKILÄ, M. (1978). Grip force in vibration disease. Scand. J. Work Environ. Health, 4, 159-166.

FärkKiLÄ, M., РүyкkKö, I., Korhonen, O. and Starck, J. (1979). Hand grip forces during chain saw operation and vibration white finger in lumberjacks. Brit. J. Ind. Med. 36, 336-341.

HARADA, N. (1986). Effect of Nifedipine (Adalat) on vibration syndrome. J. Jap Coll Angiol. 26, 403-408 (in Japan)

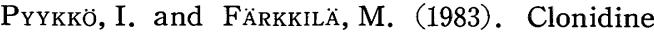
in the treatment of vibration induced white finger. In Proceedings of the International symposium on the Protection of Workers Against Vibration, Nis, 21-24. 9.82; 138-145.

Pyykkö, I., Sairanen, E., Korhonen, O., Färkillä, M. and Hyvärinen, J. (1978). A decrease in the prevalence and severity of vibration induced white fingers among lumberjacks in Finland. Scand. J. Work Environ. Health 4, 246-254.

Pyykkö, I., Korhonen, O., Färkkilä, M., Starck, J., Aatola, S. and JÄntti, V. (1986). Vibration syndrome among Finnish forest workers, a follow up from 1972-1983. Scand. J. Work Environ. Health, 12, 307-312.

Starck, J., Färkillë, M., Aatola, S., Рүүккö, I. and Korhonen, O. (1983). Vibration syndrome and vibration in pedestal grinding. Brit. J. Ind. Med. 40, 426-433.

Koskimies, K. Färkkï̈, M., Рүyкkö, I., Jäntti, V., Starck, J., Aatola, S. and Korhonen, O. (1989). Carpal tunnel syndrome and vibration syndrome. (Submitted for publication.) 